Canadian Journal of Family and Youth, 11(1), 2019, pp. 444-447

ISSN 1718-9748@ University of Alberta

http://ejournals,library,ualberta.ca/index/php/cjfy

\title{
The Beautiful Lie
}

\author{
Theresa Poirier
}

One minute they're here, the next they're gone. I can't say where they come from or where they go...because I don't know. I can tell you they make me an outsider, so I keep my visions to myself. They come as apparitions, premonitions and dreams. My mother brushed them aside, reducing them to lies and lunacy. Leaving home was relief. I ran. I ran from Nova Scotia to British Columbia. I've been running since.

I ran into trouble. Anxiety, depression and panic attacks sound sick; but that's my normal. They're described in the Diagnostic \& Statistical Manual of Mental Health (DSM). Not listed are sociopath...psychopath and crazy, they should be. Crazy drove my common-law Jack to poison me twenty years ago.

There was no warning of madness. No vision. That rat bastard put poison in baking soda I used to brush my teeth. I spat. I gargled. I didn't dare swallow. I asked him to call an ambulance. He said, "No...they'll think I did it."

Holy fuck...you did. I'm living with a maniac. At that time, we were renting a flat in a four story walk up in Richmond. I hid in my room, guarding the door, making the bathroom once a day for water and a piss. A vision came the third day.

I saw my first ex Phil. His translucent manifestation sat in the corner, "Get up. If you 
don't get up, he’s gonna kill you."

I shot upright like a reflex in a corpse. "Are you dead?"

"This is not about me. This is about you. Get up...go...now."

I did. I ran. I landed in Edmonton on my brother's doorstep.

Ten years after, a different kind of insight hit me. Spread out on my dad's couch I got a gut feeling, a premonition. This would be the last call for my dad and me. At home I wept, lumbered about. Click Click caught my attention. My TV came on. I gasped. I spied a handful of kids listen to clowns as they sang, "Don't be sad; be happy today. Don't you cry; I'm on the way. Don't be blue, I'm here for you..."

I drop into a chair recovering I reminisced taking comfort in the knowledge there was an afterlife.

\section{$* * *$}

When my dad was alive my parents would head to Arizona every fall. The trip was a nonstop party. Except one year my mother ran off with an American. Everything I did, my mother had to one up me. I left Jack, she left dad...for another man. Dean. Four years later she was relocating to Canada. She lands on my doorstep in Edmonton. She found an apartment in Creston, and she was gone.

She became a nursemaid to Dean. Falling ill herself, they opted for a retirement home. The Valley View. Dean was assigned to a room...my mother admitted to hospital. Moving was good for the care they needed. Also good for my older brother Mark. He lived in the area and could visit. I could only call.

Mark's a burn out. A lazy hippy. He'd show up at my mother's bedside with stragglers 
The Beautiful Lie

he'd pick up at the bar. He was drugged, drunk, and dumb.

One day she said, "I'm dying. I'm afraid for Mark." He had no control over his emotions and his explosive temper landed him in the loony bin more than once.

“Tell Mark I'm dying. I'm afraid to...he'll go off the deep end... you know he's nuts. And tell him not to bring those drunks he digs up."

Hoping to comfort her I told my dad's tale of afterlife. "Bah. You smoke too much pot. You're crazy."

I begged off.

Mark had to call from a friend's phone as he had none of his own.... a true hermit; and I had to wait four weeks for the call to disclose my mother's impending death.

Mark reacted... went nuts. Retelling dad's tale of afterlife was ineffective. "You're crazier than me."

But he agreed...no more drunks. He flung himself into depression, yet managed a daily brunch. They ate her favorite... Rice Krispies and toast. Soon she faded in and out of consciousness. Four days after the call the vision came to me in a dream.

I spied a ceiling-less corridor, dark... stretching toward infinity on the left, swinging doors on the right. I enter and the hub of life close behind me like a zipper. I spotted my mother. She rested in an incubator case on wheels. She rolled by. Her case moved in tandem within an infinite line of others pulling toward the doors. Light beamed back through the windows on the doors. I squinted. I couldn't make faces in the other cases but I knew they contain people. Her head sat disproportionately larger than her body...like a newborn. A white sheet covered her tiny frame. An oxygen mask obscured her nose and mouth. Her eyes bulged. As the case 
streamed by me she said, "I'm tired. I hurt. I'm going." Two figures in garbs of white tended to the incubator case as it approached the doors. They open, then close. She was gone.

Within days my mother was dead. For days later and every three months or so, a solitary Rice Krispy appeared next to the utensils I inherited.

I still get visions, but I quit running. 